\title{
The part of organic acids in the germination of seeds
}

\author{
R. W. SCHRAMM
}

The germination of seeds is a very complex process, so far not understood in all its details, and which is affected by a great many physical and chemical factors. A seed is not a typical plant organism since it is deprived of chlorophyll and consequently the ability to photosynthetize, which forces it to rely entirely on the accumulated storage materials in the early part of its development.

Seeds in the dormant state contain, apart from the basic storage materials, also a certain amount of organic acids, most of them bound into salts (Sołdatienkow and Mazurowa 1956a) or to sugars through glucoside links (Harborn and Korner 1963; Sołdatienkow et al. 1965). The problem of organic acid metabolism in seeds is discussed in the article by Fowden and Moses in the XIIth volume of the Encyclopaedia of Plant Physiology (Fowden and Moses 1960).

It can be assumed that if certain acids can in natural conditions participate and play a part in the germination process then these will be acids: a) occuring universally in all seeds and b) present in the seeds from the moment they have reached their ability to germinate.

In all mature seeds only two acids occur always, namely citric acid and malic acid. In recent years many seeds, mainly from the Leguminosae, have been found to contain large amounts of acids which are not the products of any known metabolic pathways. These acids, with their structures not yet known exactly, differ from the aldonic and uronic acids and are empirical isomers of simple sugars, presumably arising as pıoducts of primary oxidation of the sugars (Soldatienkow and Mazurowa 1956b). In the following parts of this paper these acids will be refered to as sugar acids (although this definition contain all types of oxidised monosacharides wi.h carboxylic groups). It is not unlikely that they represent a common constituent of all seeds. Apart from those mentioned above much lower quantities can be found, and this only in some species of plants, of aliphatic acids such as oxalic, tartaric, aconitic (in cereals), malonic (in Leguminosae), volatile acids, with acetic in the first place (mainly in oily seeds), lactic acid, various keto-acids and others. Several seeds contain also large quantities of cyclic and aromatic acids such as quinic, benzoic, cinamic, and phenolic acids as for example salicylic, caffeic, hydroxycynnamic, chlorogenic etc. 
Some of these acids are products of basic and intensive metabolic processes, namely: citric, malic, keto-acids - of the tricarboxylic acid cycle (TCAC), lactic acid - of glycolysis (EMP). Quinic acid represents the substrate for the synthesis of several cyclic compounds. On the other hand aromatic and phenolic acids, which are products of lateral metabolic pathways, play in the germination process itself the role of distinct and common inhibitors. They occur much more frequently and in greater quantities in the fruits (fruit wall) then in the seeds themselves (Varga 1957; Köves and Varga 1959; Van Sumere 1960; Mayer and Poljakoff-Mayber 1963). Also oxalic acid, whose role in plant metabolism is still unclear, has proved to be a germination inhibitor of some seeds (Gal 1938; Błagowieszczenskij and Kołogriwowa 1945; Miyamoto 1957). Tartaric acid, which is chemically similar to malic acid and presumably is able to replace it in some reactions (Gomółka 1959; Krampitz and Lynen 1964) is actually metabolized by plant tissues, though rather weakly (Pantelejew and Kluszewa 1966). Small quantities of lactic acid, keto-acids as well as the volatile acids appear to be products of changes taking place in the seeds during dormancy. Air dry seeds demonstrate such minimal metabolism that practically it has been assumed to be equal to zero, hovever in the very difficult diffusion conditions in the seed this minimal metabolism during the dormant state can after a period of time lead to the accumulation of small yet analytically discernible quantities of certain compounds. On the other hand citric acid and malic acid which are constituents of TCAC, as well as sugar acids and occasionally in some species also other acids as aconitic, or oxalic, can be found in mature seeds in quite large quantities in comparison with others, which could be considered as normal metabolic products, sometimes exceeding several percent of dry weight (Munch-Petersen 1944). These quantities are all the more striking if we consider that cells of seeds are devoid of vacuoles in which normally the major part of organic acids are to be found (Bennet-Clarck and Bexon 1943).

Both citric and malic acids accumulate in large quantities in the seeds during their growth. In immature seeds praticularly large quantities of malic acid are to be found at the expense of which the content of citric acid increases during the maturation of the seed (Tombesi et al. 1955; Sołdatienkow 1962, Evenari 1965). This presumable takes place as a result of some irr gularities in the functioning of TCAC, which interfere with the normal oxidation of acids, possibly in the case of citric acid in an analogous way as the accumulation caused by some moulds (Lewis and Weinhouse 1951; Ramakrishnan 1954; Ramakrishnan at al. 1955) or in the potato tubers (Laties 1964). The possibility that a part of the citric acid is formed from quinic acid also cannot be excluded (Carles 1957). Also the acids which are the products of the primary oxidation of sugars (sugar acids) are $\operatorname{presen}^{t}$ in the seeds already at the time the seeds art reaching maturity (Soldatienkow and Mazurowa 1956a; Schramm 1961), however at present there is not much information concerning their biosynthesis and the time of their apperance in the seeds.

It can therefore be assumed that citric and malic acids and possibly also the 
sugar acids play a universal and most important role in the process of seedsgermination. This role may depend on the two basic functions:

1) supply of a direct easily u'ilizable substrate for metabolic reactions, and

2) conditioning of the metabolic reactions taking place and directing them.

The studies conducted so far on the organic acids in seeds concerned the enzymes associated with their turnover rather than with the acids themselves, their distribution and quantitative fluctuaions (Fowden and Moses 1960). The bulk of the organic acids in seeds is localized in the storage tissues (cotyledons, endosperm), however their percentage concentration in the embryonal tissues can be often much higher (Schramm et al. 1967). During the process of seed germination the content of organic acids increases with the result that the slightly basic medium of the embryo during dormancy turns acidic on germination (Pack 1921). Cumulative studies indicate a continuing increase of the acids content in the embryonal axis and a decline in the cotyledons (Meiss 1952; Schramm et al. 1967).

It is still not known where within the cell are the organic acids accumulating. It is possible that the accumulation, at least with respect to a substancial part of the acids, takes place in the mitochondria, which in the seeds are well developed (Öpik 1965), similarily as is the case in animal tissues, where in the mitochondria about $70 \%$ of the citrate for the whole cell is bound (Schneider et al. 1956). Isolated mitochondria of animal tissues are capable of a very strong and rapid accumulation of citrate, and also, though less strongly, of malate in contrast to other acids participating in TCAC. The concentration of citrate in the mitochondria of rat liver can be 15 times as strong as in the medium (Amoore 1958; Gamble 1965). The role of this accumulation is quite unexplained, and most likely it is not direcily associated with the oxydation processes. In any case these acids while in the mitochondria undergo only a very slight metabolism (Plaut and Plaut 1952; Gamble 1965). The situation in the germinating seeds appears to be very much the same (Öpik 1965).

Most information is available about citric acid and slightly less about malic acid while the studies on the turnover and role of the sugar acids are only beginning. This is associated with the methods of quantitative determination, which for the sugar acids are still lacking.

The relative quantitative propotions of these acids vary from one plant species. to another. Seeds of the Leguminosae, in which the content of the acids reaches several (Täufel and Pohloudek-Fabini 1955a, Sołdatienkow and Mazurowa 1956a) and sometimes even more than a dozen percent of dry weight (Pierce and Appleman 1943), are notable in that they contain the greatest concentration of acids. Also the Leguminosae demonstrate a definite abundance of citric acid, more than 10 times as much as the seeds of cereals and several times as much as the seeds of oily plants (Munch-Petersen 1944, Sołdat ienkow and Mazuro- 
wa 1954, 1956a, Täufel and Pohloudek-Fabini 1955a). Gobis (1951) believes that the high content of citric acid is associated with the synthesis of proteins in the setds. On the other hand the content of malic acid does not vary so much between the species (see Table 1).

Table 1

Content of citric and malic acid in mature seeds of various plant species in $\mathrm{mg} / 100 \mathrm{~g}$ of dry weight. (Data taken from Sołdatienkow and Mazurowa 1954; Täufel and Pohloudek-Fabini 1955 a; Schramm et al. 1967).

\begin{tabular}{l|l|c|c}
\hline \multicolumn{1}{c|}{ Seed } & Species & Citric acid & Malic acid \\
\hline \begin{tabular}{l|l} 
Starchy \\
(cereals)
\end{tabular} & Barley & 70 & - \\
& Oats & 62 & - \\
& Rye & 69 & $14-59$ \\
\hline & Wheat & $12-78$ & - \\
Oily & Rape & 198 & 180 \\
(oleaginous) & Sunflower & $66-160$ & 40 \\
& Flax & $90-207$ & 60 \\
\hline & Hemp & 90 & $47-132$ \\
Protein & Horsebean & $408-659$ & 67 \\
(Leguminosae) & Pea & $290-803$ & 270 \\
\hline
\end{tabular}

Within the seed itself the distribution of acids is also not uniform. It is generally assumed that citric acid accumulates primarily in the embryo (Carles 1960), however this is not always the case. In cereals the embryo contain several times higher concentration of citric acid than the endosperm in relation to the dry weight ( $\mathrm{T}$ äufel and Krusen 1952). Conversely in horsebean the content of citric acid in dry seeds is in embryo almost half as large as in the cotyledons, while the content of malic acid is twice as high (Schramm et al. 1967).

Citric acid can be found throughout the living world in all tissues in which intensive biochemical and physiological processes take place (Täufel and Behnke 1956, Srere 1965). As regards its role in the seeds, some investigators have suggested that it could in certain conditions perform the function of a reserve substance that is used when the plant reaches a level of trophic deficit, for example during etiolation (Dupéron 1958a), however most of the observations seem to contradict this.

In germinating seeds the level of citric acid undergoes a clear alteration, however in this respect the results of various investigators are contradictory. For example in the Laguminosae some observe a drop in the level of citric acid (Gobis 1951; Täufel and Pohloudek-Fabini 1954, 1955a; Czesnokow et al. 1955; Sołdatienkow and Mazurowa 1956a; Dupéron 1958a), while others observe its increase (Munch-Petersen 1944; Buruiana et al. 1959; Schramm 1961). A detailed analysis of the various parts of the seed and of the young seedling 
indicate that the total amount of the citric acid in the seed and seedling decreases progressively during the 15 days of germination in light to a level equal to $1 / 3$ of the original content. In darkness there is also a drop in its level however it is much less regular and much smaller. This los is caused entirely as a result of the lowering of citric acid in the cotyledons (Schramm et al. 1967). In the embryo only in the first day of germination there is a drop in the level of citric acid to about a half of a original value. During the further course of development of the seedling the content of citric acid in the root returns to tho original value in the embryo and is mainatined at this level without further changes. On the other hand in the epicoiyl it increas $\sim$ s very substancially uncil the shoot breaks away after which it drops again when the leaves start to appear (Alquier-Bouffard and Carles 1963), stabilizing at a level several times higher than that which was originally in the embiyo (Schramm et al, 1967).

Comparison with the dry weight of the cotyledons demonstrates that the drop in the level of citric acid is more or less proportional to the lowering of the mass of the whole organ. In horsebean germinating in light the content of citric acid in the cotyledons decreases very slowly and regularly from about $4 \mathrm{mg} / \mathrm{g}$ of dry weight during the first 5 days to about a half of that value in the 15th day, which is still a high concentration (above $2 \mathrm{mg} / \mathrm{g}$ of dry weight). In darkness there are almost no changes in the content of citric acid in the cotyledons and towards the end of germination (15th day) there is an increase in its content (Schramm et al. 1967). Only after complete utilization of the storage compounds in the cotyledons does a clear drop in the content of citric acid begin (Buschbeck 1964).

These data seem to indicate that a direct utilization of citric acid may take place only in the first day of germination when there is a strong drop in its content both in the cotyledons and in the embryo. On the other hand the further lowering of the citric acid content in the cotyledons, which is at all times proportional to the decrease in the mass of the whole organ, appears not to play any direct and significant role in the process of germination (Buschbeck 1964; Schramm et al. 1967).

In the seeds as well as in all other plant tissues rich in organic acids, the majority of acids appear to be spatialy separeted from the sites of respiratory processes and only a small part of them can enter the metabolic pool (Vickery and Zelitch 1960; Laties 1961; Mc Lennan et al. 1963). This appears possible even in the case of accumulation of the acids in the mitochondria (Gamble 1965). It cannot be excluded however that certain quantities of citric acid are utilized in germinating seeds for the extramitochondrial synthesis of fatty acids essential for th: formation of the lipid layer on the plasmatic membranes in the intensively forming new cells and mitochondria (Hackett 1963), analogous to the same process taking place in the animal tissues (Formica 1962; Kallen and Lowenstein 1962; Srere and Bhaduri 1962; Spencer and Lowenstein 1962; Spencer et al. 1964; Bhaduri and Srere 1963; Kornacker and Lowenstein 1965) particularily in the first period of seed germination when the decline in citrate level cannot be explained in terms of oxidation in TCAC (Schramm et al. 1967). 
The situation with malic acid is somewhat different. This acid is present in the Leguminosae in higher concentrations in the embryo than in the cotyledons (Schramm et al. 1967). Overall studies indicate a general increase in the level of malic acid in germinating seeds (Czesnokow et al. 1955; Sołdatienkow and Mazurowa 1956a). More detailed observations indicate that this process is limited to the embryo only. In the developing axis of the seedling the amount of malic acid increases very rapidly, both in the shoot and in the root. The level reaches a stable value, several times higher than that of citric acid, when the seedling develops new green organs. On the other hand the amount of malic acid in the cotyledons after an initial increase in the first few days of germination, stronger in darkness than in light, declines in the 15th day similarily as citric acid, to $1 / 3$ of its original value. However, converting these results to a per dry weight basis, the concentration of malic acid in the cotyledons does not undergo any changes (Schramm et al. 1967).

Malic acid is generally much more reactive than citric acid. It is the first to appear in plants (Sołdatienkow 1962), it is most readily oxidised (Poljakoff-Mayber and Evenari 1958), it undergoes changes under the influence of light (Vickery 1956; Poljakoff-Mayber and Evenari 1958; Truelove 1962), it turns relatively easily into the acids other than those of TCAC (Spencer and Lowenstein 1962; Truelove 1962), and it forms the basic carbon skeleton for a whole series of organic compounds synthetized in the plant (Kursanow 1954, 1957a, b). Both malic and citric acid are associated in the plant with the metabolism of the two most important cations namely calcium and potassium (Rasmussen and Smith 1961; Palmer et al. 1963) and they can form paricularily with the potassium ion a buffer system (Wilkinson 1958; Richmond et al. 1964).

It is known that in green tissues of plants citric acid and malic acid are in a state of certain equilibrium, which is primarily regulated by light. In light citric acid is converted to malic and in darkness the opposite is true, that is malic acid is converted to citric. This latter process takes place much more easily and quickly (Czesnokow et al. 1955, 1960; Vickery 1959; Sołdatienkow 1962; Truelove 1962). The conversion of malic acid to citric is possible in plants along two pathways. In TCAC oxaloacetic acid is condensed with an active acetylate fragment and with a water molecule which is catalysed by the ,condensing enzyme" (citrate syntethase) (Hiatt 1962). Malic acid can also be condensed with glycolic aldehyde arising from hexoses (Sołdatienkow 1962). The turnover of citric and malic acids is associated with the influence of light on the enzymes directing them. In particular the enzymes directly associated with the turnover of malic acid are sensitive to light (Vickery 1956).

At the moment the sufficient number of studies is lacking in order to be able to conclude how these processes operate in the seeds, it is however known that light plays a very important role in the germination process (Borthwick et al. 1954; Ikuma and Thimann 1960, 1963; Mayer and Poljakoff-Mayber 1963; Rollin 1964).

The ratio of malic and citric acid content changes during the germination process 
very strongly. It is low in oily and protein seeds during dormancy and high in the starchy seeds. During germination it grows very strongly in the oil and protein seeds and declines in the starchy seeds (Radecke 1965). A detailed analysis conducted on the seeds of horsebean indicates that large changes take place primarily in the root and in the shoot, and are associated very clearly with appearance of green organs and the onset of the photosynthetic process (Schramm et al. 1967).

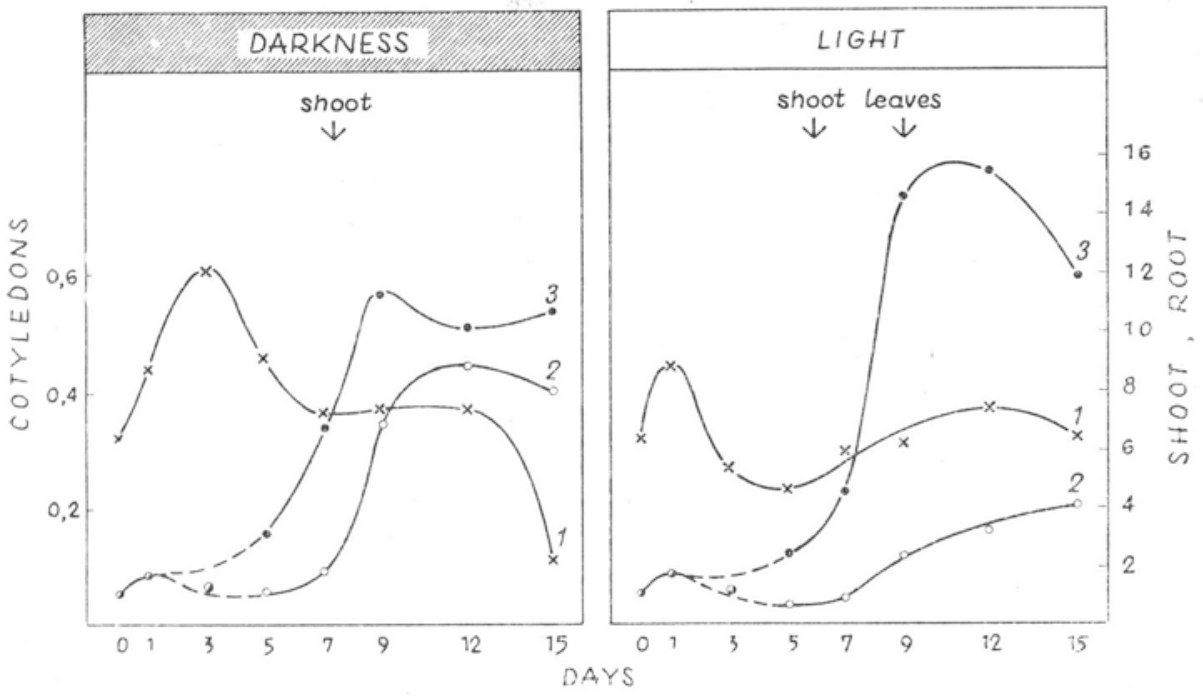

Fig. 1. Ratio malic: citric acid in the germinating seeds and young seedlings of horsebean (Vicia faba L. minor) both in the darkness and in light. (Culture on distilled water).

On the other hand in the cotyledons greater fluctuations take place only in early period and in the darkness towards the end of their functioning (Fig. 1).

Changes taking place in the content of citric and malic acids are also dependent on temperature. An increase in temperature favours the decomposition of citric acid while a lowering of temperature leads to utilization of malic acid and to accumulation of citric one (Schramm 1961; Buschbeck 1964).

At the moment we do not know very much about the changes taking place in sugar acids during germination, which is the result of generally inadequate number of studies on these compounds, and in particular a lack of a satisfactory method of their quantitative determination. Pathways of their metabolism are directly associated with the carbohydrate turnover and particular with the pentosphospahte pathway (Sołdatienkow and Wajnsztein 1966), and with the di- and tricarboxylic acids (Sołdatienkow and Bykow 1964). In certain conditions the acids can be utilized by the plants as a substrate of metabolic processes (Schramm 1961; Soldatienkow and Bykow 1964). Large quantities of these acids can be found particularily in the seeds of the Leguminosae, where they can constitute more than $50 \%$ of the total content of organic acids (Schramm 1961). Almost the same con- 
centration, and in absolute values much more of these acids can be found in the lea. ves (Sołdatienkow and Mazurowa 1956a). In the axis of a seedling (shoot and root) big changes in their content take place, similarily as in the case of citric and malic acids, with a tendency to stabilize at a high level on the appearance of the leaves. In the cotyledons the content of these acids remain more or less at the same level until the shoot breaks away, after which they increase several times over when the leaves appear, however they never approach half the content in green organs and in the roots (Schramm 1961). These acids appear to represent a transitory product with an unknown but reversible turnover that does not pass through glycolysis or TCAC, between the carbohydrates and malic acid (Biełozjerowa and Sołdatienkow 1963).

On the basis of the data presented it can be assumed that organic acids present in the seeds play an important role from the very beginning of metabolism in the embryo and the seedling axis, but do not participate or participate only to a slight degree in the metabolism of the cotyledons which during germination play a significant and very active role, difficult to replace especially in Leguminosae (Czosnowski and Michejda 1964).

It can be supposed however that the presence of relatively large and constant concentrations of acids in the cotyledons can play during germination a regulatory role with respect to the metabolic processes taking place.

\section{III}

Shortly after the commencement of imbibition, after a short period of mechanical water uptake (Czosnowski 1962), there begin in the seed and rapidly reach a great intensity various metabolic processes associated both with the liberation of energy and with the formation of initial products essential for the necessary syntheses, particularily of proteins, that is in the first place a hydrolysis of macromolecular storage compounds, then glycolysis, the pentosephosphate pathway, the tricarboxylic acid cycle (TCAC), the glyoxylic acid cycle (GAC), and the $\beta$-oxidation of the fatty acids. At the same time there is a rapid increase in the number of mitochondria (Hackett 1963) which occur in a fully developed form already in the mature seeds (Öpik 1965).

Unfortunately we know very little so far about the activity of various processes in germinating seeds and about their mutual interdependence, as well as about the localization and activity of these processes in various parts of the seed. The respiratory mechanism of the various parts of the seed is not the same (Stiles 1960). As a result of the large mass of storage tissues (cotyledons, endosperm) in proportion to the embryo the cumulative picture of the respiratory metabolism of the whole germinating seed is dominated by the metabolism of the cotyledons in the first place (Stålfelt 1926). However, the detailed studies of several authors conducted primarily on the seeds of cereals indicate that as a proportion of the mass of an organ the respiration of an embryo is several dozen times higher than of the endosperm (Stiles 1960). The situation is similar in the Leguminosae. 
Relatively speaking the best known respiratory function is the glycolysis (EMP), the activity of which in germinating seeds is beyond discussion (Stumpf 1952, 1960; Hatch and Turner 1958; Millerd 1960; Beevers 1961; Mayer and Mapson 1962). TCAC is generally accepted as the main pathway of metabolism in germinating seeds (Turner and Quartley 1956; Truelove 1962), however the conditions prevailing in the seeds do not favour aerobic reactions. Paralell with TCAC oxidative phosphorylation takes place (Conn and Young 1957; Laties 1957; Switzer and Smith 1957). More delailed studies indicate that of the carbohydrates metabolized in the germinating seeds at the most $50 \%$ are oxidized through TCAC (Beevers and Gibbs 1954; Gibbs and Beevers 1955; Mapson and Moustafa 1956; Pritchard 1961; Viñuela et al. 1964) and the activation of TCAC does not take place until after a certain time (Evenari 1965) necessary for the swelling and attainement of full activity by mitochondria. Citric acid is particularily difficul to oxidize (Poljakoff-Mayber and Evenari 1958). O ot a and collaborators $(1954,1956)$ were unable to find the isocitrate dehydrogenase in the cotyledons of germinating Vigna sesquipedalis seeds, however they did find the malic and $\alpha$-ketoglutaric dehydrogenases. On the contrary, the isocitric dehydrogenase was active in the radicule, the hypocotyl and in particular in the plumule. From these $r$ ssults the authors have concluded that there is a lack of TCAC activity in the cotyledons and point out the very great differences in the oxidation mechanism between the cotyledons and the embryonal axis. The glyoxylic acid cycle (GAC) is not observable in the germinating seeds of cereals and the Leguminosae (Carpenter and Beevers 1959), however it is a normal metabolic pathway in oily seeds together with the $\beta$-oxidation of fatty acids (Carpenter and Beevers 1959; Zelitch 1964). Data on the pentosephosphate pathway in the seeds are very scanty (Mayer and Poljakoff-Mayber 1963). This pathway plays a generally significant role in plants as a supplier of large quantities of reduced NADP $\left(\mathrm{NADPH}_{2}\right)$ for the reducing syntheses (Axelrod and Beevers 1956; Lowenstein 1961; Hackett 1963) however it does not supply energy direcily, since its enzymatic system is not associated with the mitochondria (Forti et al. 1959), and the reoxydation of $\mathrm{NADPH}_{2}$ generally runs through the system of ascorbic acid oxidase and the phenolic oxidases (Lowenstein 1961; Hackett 1963). In germinating seeds it can be active besides EMP both in the embryo (Gibbs 1959) and in the cotyledons (Wray and Brown 1966).

The internal control of the respiratory mechanism in plant tissues is achieved through an interaction of several factors directly or indirectly associated with the concentration of oxygen (Pasteur effect, ratio ADP : ATP, ratio NAD : $\mathrm{NADH}_{2}$; Turner 1960; Beevers 1961; Hackett 1963). The action of all these factors reflects itself primarily on the glycolytic process (EMP).

It is reasonable to suppose, that in the conditions of poor oxygen supply and necessity to activate the most efficient energy systems, which exist in germinating seeds, the plant organism will employ supplementary regulatory factors which will tend to divert he respiratory mechanisms towards the most efficient pathway. 
It is not unlikely that one of such factors is the activity of the non metabolic pool of organic acids in the seeds.

\section{IV}

It seems to be beyond doubt that the germination ability of seeds of a whole series of plant species is associated with the presence in them of a certain amount of citric acid (Täufel and Pohloudek-Fabini 1954, 1955b; Täufel und Behnke 1956; Pyriki and Kunst mann 1956; Sabala 1962). In coniferous trees it has been found that soaking of seeds for 4 days in a $0.01 \%$ solution of citric acid distinctly increases their germination ability in comparison with seeds soaked in pure water (Cotrufo 1962, 1963). However this phenomenon is not a rule for all seeds, since the same treatement in relation to other species may not have any effect or it may even have an inhibitive effect (Gal 1938; Evenari 1949). Moreovei, it has not been established yet to what extent the inhibitive activity of organic acids on the germination of seeds is causc d by the specific activity of the anion and to what by the increase in the hydrogen ion concentracion (decrease in pH (Evenari 1949). The synergistic effect of $\mathrm{pH}$ on the activity of many promoters as well as inhibitors on the course of germination is very clear. For example almost all the TCAC acids were found to be promoters of germination of the seeds of tobacco at a $\mathrm{pH}$ of about 4,8 , acting together with gibbcrellins. On the other hand over a wide range of $\mathrm{pH}$ values only malic acid proved to be a strong activator and for a somewhat narrower range also tartaric acid (Takahashi et al. 1962).

The great requiremeni for energy in a germinating seed should theoretically from the very first moment lead to the activation of the most efficient mechanisms, that is the TCAC coupled with the oxidative phosphorylation, this however is associated with a large demand for oxygen. Before the rupturing of the seed coat by the swelling seed there exist inside conditions of complete or at least very strong anaerobiosis (Frietinger 1927), while at the same time there is a gradual increase in $\mathrm{CO}_{2}$ release (Stiles and Leach 1932) which cane originate either from alcoholic fermentation or from the oxidation of sugars through the pentosephosphate pathway. Only after the seed coat is rupiured there is a rapid increase in the respiration intensicy as a result of a major change in the method of supplying the seed with oxygen (Síålfelt 1926; Stiles and Leach 1932; James and James 1940). Under prolonged conditions of complete anaerobiosis, for example when the oxygen supply is replaced by nitrogen, germination does not take place at all (Ikuma and Thimann 1964), however for a certain period of time the process of glycolysis can proceed though at a low intensity (Wager 1961). Under normal conditions of germination with oxygen supply, the compact structure of the cotyledons and endosperm presents considerable difficulties in the rapid diffusion of oxygen to sites of anabolism of the storage substances, which predisposes the anaerobic path of respiration - glycolysis to a more privilaged activity, the result of which is the accumulation of lactic acid and ethanol in the germinating seeds (Stoklasa 1926; Schneider 1941; Phillips 1947; Barker and el Saifi 
1952; Wager 1961; Simonet al. 1963; Cossins 1964). This activity can be further intensified by the simultaneous appearance of glyoxylic acid in the germinating seeds which arises either from fatty acids throuhg GAC (Carpenter and Beevers 1959; Cotrufo 1962) or as a result of nitrogen metabolism (turnover of ureides and some amino acids; (Krupka and Towers 1958a, b; Fowden and Moses 1960) or finally from green tissues (also from greening cotyledons) under the influence of light and activity of the glyoxylic acid oxidase (Kuczmak and Tolbert 1962). This acid joins with oxalacetic acid produced either by the TCAC or through direct carboxylation of pyruvic acid under the influence of pyruvic acid carboxylase (Tchen and Vennesland 1955; Tchen et al. 1955) or from the process of citrate decomposition in the reaction of ATP with $\mathrm{C}_{\mathrm{o}} \mathrm{A}$ (ATP citrate lyase; Srere and Lipmann 1953; Srere 1959). The joint product of these two acids is the $\gamma$-hydroxy- $\alpha$-ketoglutaric acid (Payes and Laties 1963), which inhibits TCAC checking the oxydation of the citrate (Ruffo et al. 1962). A very similar acid, $\gamma$-methylene- $\alpha$-ketoglutaric acid has been found in considerable quantities by Fowden and Webb in the germinating seeds of Arachis hypogaea (Fowden and Webb 1955; Webb and Fowden 1955) however it appeais that its synthesis is along a different path. Also this acid can presumably play the role of TCAC inhibition at the stage of oxidative decarboxylation of the $\alpha$-ketoglutaric acid, in the same way as another acid, very close to both the ketoacids refered to above, $\gamma$-methyl- $\gamma$-hydroxy- $\alpha$-ketoglutaric acid, has been found to inhibit. This latter acid has also been isolated from plants (Montgomery and Webb 1954).

Under these conditions there appears to be a need in the seeds, besides the regulatory system of the respiration process occuring normally in plant tissues, of an additional factor stimulating TCAC and the oxidative phosphorylation. This role could be played by the citric and malic acids, which are the only natural components of TCAC that are at the same time its strong stimulators. One can well imagine that these acids, even from the pool not being metabolized, exert a certain pressure on TCAC not permitting a decline in its activity under unfavourable conditions. Such pressure, causing an intensification of TCAC activity, should lead to a stimulation of the active oxygen absorption which in turn is associated with the increase of citric acid content in the metabolic pool (Barker 1963).

Citrate acts on a whole series of enzymes involved in turnover of sugars with a general tendency for the stimulation of of the aerobic phase of the oxidation-reduction processes and an inhibition of the anaerobic one. In particular the citrate at physiological concentrations $\left(2 \times 10^{-4} \mathrm{M}\right)$ strongly inhibits phosphofructokinase (Garland et al. 1963; Parmeggiani and Bowman 1963; Passonneau and Lowry 1963; Sanval et al. 1963). In TCAC the citrate removes the inhibition of aconitase caused for example by fluoroacetate (Williamson et al. 1964). It specifically activates the isocitrate dehydrogenase (Sanval et al. 1963) whereby inhibition results of the citrate lyase, which catalyses the formation of glyoxylic acid. Finally it also strongly activates fumarase (Massey 1953). The intensificaiion of TCAC leads to an increase in ATP synthesis, which in its turn inhibits glycolysis both indirectly through a reduction of ADP essential for the conversion of fructose-1,6- 
-diphosphate into pyruvic acid, and actively acting as an inhibitor of the phosphofructokinase (Lowry and Passonneau 1964a, b) and the glyceraldehydophosphate dehydrogenase (Mossberg et al. 1964). Action on the phosphofructokinase is however not universal since for example in the parsley phosphofructokinase is not inhibited by ATP but by ADP, and yeasts contain two phosphofructokinases, one sensitive to ATP inhibition and other not. Both these forms can under certain

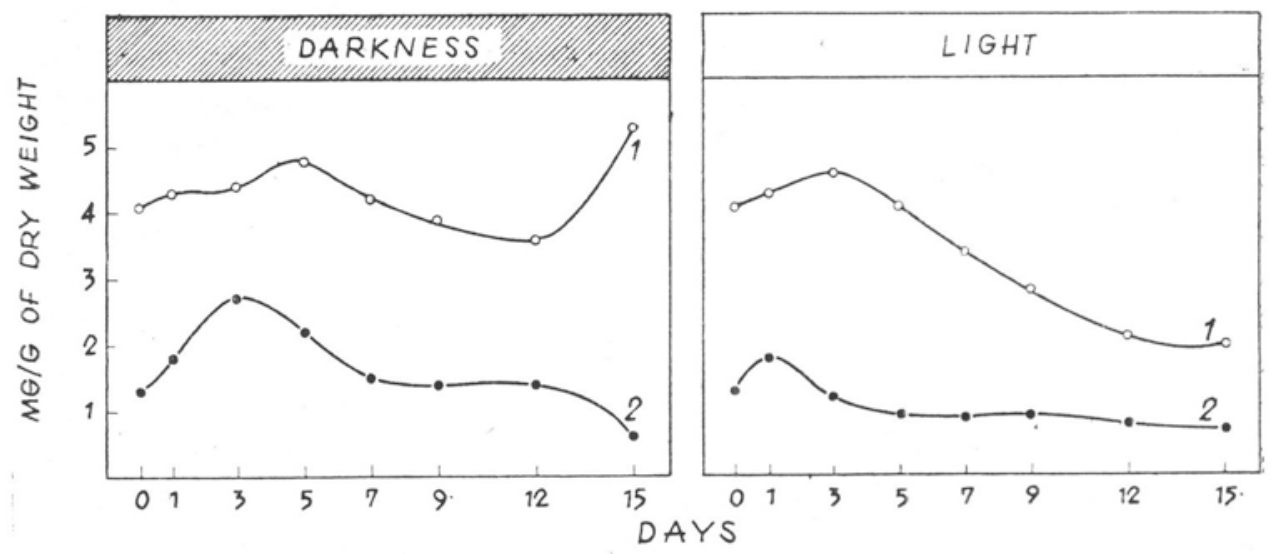

Fig. 2. Changes in the content of malic and citric acids in the cotyledons of germinating seeds and young seedlings of horsebean (Vicia faba L. minor) both in the darkness and in light. (Culture on distilled water).

1 o - o citric acid; 2

- malic acid

conditions convert from one to the other (Vi ñuela et al. 1964). Citrate in somewhat higher concentrations $\left(10^{-2} \mathrm{M}\right)$ can also act in the synthesis of fatty acids not only as a direct substrate used in the reaction but also as an activator of the reacion stimulating the activity of the aceiyl-CoA-carboxylase and the formation of the malonyl-CoA (Martin and Vagelos 1962).

Malate acts similarily by the stimulation of the oxidative decarboxylation of pyruvic acid, the formation of the acetyl-CoA and the synthesis of citric acid (Stanley and Conn 1957) as a result of which it becomes a direct activator of TCAC and of the oxidative phoshorylation, playing a direct role in the ATP economy and the regulation of oxidative processes: oxydation of carbohydrates through glycolysis and $\beta$-oxidation of fatty acids (Hird et al. 1966). Malate, as a result of the ease with which it passes through the mitochondrial membrane and the activity of the malate dehydrogenase, also plays an important role as an intracellular regulator of the intra and extramitochondrial level of the reduced nicotinamide nucleotide $\left(\mathrm{NADH}_{2} ; \mathrm{Krebs} 1966\right)$ and interacts with the pentosephosphate pathway in the production and metabolism of the reduced nucleotides essential for the reductive syntheses taking place in germinating seeds.

It cannot be excluded as a possibility that the role of citric acid and possibly also of malic acid, in germinating seeds, depends, individually for each species, on the regulation of anaerobic and aerobic phases of seed respiration. In the seeds of 
horsebean the content of both these acids in the cotyledons in relation to dry weight changes very slightly and this primarily in the period preceeding the breaking away of the shoot. In seeds germinating in the light the content of both the acids in the developing axes of seedlings increases strongly until the appearance of the leaves, after which the amount of citric acid drops (Schramm et al. 1967). In the cotyledons there is a slow but regular decline in the level of citric acid in relation to the dry weight starting already from the third day, while the level of malic acid becomes stable. In seeds germinating in the darkness citric acid reaches in the cotyledons a higher level, its later drop is of short duration and becomes stopped quickly and towards the end of germination there is a clear increase again (Fig. 2). This permits the conclusion that the role played by citric in the germinating seeds, which presumably depends on the regulation of the oxidation-reduction metabolic processes, becomes replaced in the light by the process and products of photosynthesis (Schramm et al. 1967). The situation is not altered by the fact that chlorophyll is formed in the light by the seedling. In the axial organs the process of photosynthesis is strongly connected with a change in the content of organic acids (Alquier-Bouffard and Carles 1963; Schramm et al. 1967), on the other hand this process does not take place in the greening hypogeal cotyledons, which would appear to indicate that a full, normal photosynthesizing ability and turnover in the organic acids is associated not only with the presence of chlorophyll but also with the morphological structure of the leaf (Sołdatienkow and Iwanowa 1955; Schramm et al. 1967).

\section{SUMMARY}

In the process of seed germination an active role is played by organic acids which occur universally in all seeds from the moment that germination ability is reached. They are citric acid, malic acid and possibly also the little known acids which are products of the primary oxidation of simple sugars (sugar acids). Amounts of these acids, particularily of citric acid, is different in seeds of various species. Citric and malic acids presumably play a direct role in the metabolism of the embryo and the seedling axis but not in the metabolism of the cotyledons where they are present in relatively high concentrations. It is on the other hand assumed that in the cotyledons these acids, particulary citric acid, act as regulators of the oxidation-reduction processes through the stimulation of the aerobic phase of respiration and the oxidative phosporylation. It is presumably this activity that makes citric acid essential for the germination process as has been observed by many investigators. As soon as a seedling starts to assimilate the photosyntetic process takes over the regulatory role played in the germination seeds by citric acid.

Department of Biochemistry

A. Mickiewicz University

Poznań, Stalingradzka 14

\section{REFERENCES}

Alquier-Bouffard A., Carles J., 1963, C. R. Acad. Sci. 256:3742.

Amoore J. E., 1958, Biochem. J. 70:718.

Axelrod B., Beevers H., 1956, Ann. Rev. Plant Physiol. 7:267.

Barker J., 1963, Proc. Roy. Soc. B. 158:143.

Barker J., el Saifi A. F., 1952, Proc. Roy. Soc. B. 140:385.

Beevers H., 1961, Respiratory Mechanisms in Plants, Row, Peterson and Co, Evanston, Ill. 
Beevers H., Gibbs M., 1954, Plant Physiol. 29:322.

Bennet-Clarck T., Bexon D., 1943, New Phytol. 42:65.

Bhaduri A., Srere P. A., 1963, Biochim. Biophys. Acta 70:221.

Biełozjerowa Ł.S., Sołdatienkow S. W., 1963, Fizjoł. Rast. 10:212.

Błagowieszczenskij A. W., Kołogriwowa A. J., 1945, Dokł. AN USSR, NS 48:440.

Borthwick H. A., Hendricks S. B., Toole E. H., Toole V. K., 1954, Bot. Gaz. 115:205.

Buruiana L. M., Pop L., Pop E., 1959, Stud. cercet. biochim. Acad. RPR, 2:395.

Buschbeck R., 1964, Ber. D. Bot. Ges. 77:291.

Carles J., 1957, Bull. Soc. Chim. Biol. 39:1177.

Carles J., 1960, in "Encyclopedia of Plant Physiology" W. Ruhland Ed., Springer Verl., 12:661.

Carpenter W. D., Beevers H., 1959, Plant Physiol. 34:403.

Conn E. E., Young L. C. T., 1957, J. Biol. Chem. 226:23.

Cossins E. A., 1964, Nature 203:989.

Cotrufo C., 1962, Southeast. Forest. Exp. Sta. Res. 176.

Cotrufo C., 1963, Nature 199:92.

Czesnokow W. A., Głagolewa T. A., Lubimowa M. W., 1955, Ucz. zap. LGU 186, Biol. $39,39$.

Czesnokow W. A., Żabotynskij G. Ch., 1960, Trudy Petergof. Biol. Inst. 18:3.

Czosnowski J., 1962, Acta Soc. Bot. Pol. 31:693.

Czosnowski J., Michejda J., 1964, Acta Soc. Bot. Pol. 33:335.

Dupéron R., 1958 a, C. R. Acad. Sci. 246:298.

Dupéron R., 1958 b, C. R. Acad. Sci. 247:342.

Evenari M., 1949, Bot. Rev. 15:153.

Evenari M., 1965, Prcc. Int. Seed Test Ass. 30:49.

Formica J. V., 1962, Biochim. Biopgs. Acta. 59:739.

Forti G., Tua C., Tognoli L., 1959, Biochim. Biophys. Acta 36:19.

Fowden L., Moses V., 1960, in "Encyclopaedia of Plant Physiology" W. Ruhland Ed., Springer Verl., XII/2:701.

Fowden L., Webb J. A., 1955, Biochem. J. 59:228.

Frietinger G., 1927, Flora 22:167

Gal E., 1938, Nature 142:119.

Gamble J. L., 1965, J. Biol. Chem. 240:2668.

Garland P. B., Randle P. J., Newsholme E. A., 1963, Nature 200:169.

Gibbs M., 1959, Ann. Rev. Plant Physiol. 10:329.

Gibbs M., Beevers H., 1955, Plant Physiol. 30:343.

Gobis L., 1951, Ann. Sperim. Agric. 5:571.

Gomółka B., 1959, Acta Soc. Bot. Pol. 28:3.

Hackett D. P., 1963, in "Control Mechanisms in Respiration and Fermentation" B. Wright Ed.,

Ronald Press Co, New York, 105.

Harborn J., Korner J., 1963, Biochem. J. 81:242.

Hatch M. D., Turner J. F., 1958, Biochem. J. 69:495.

Hiatt A. J., 1962, Plant Physiol. 37:85.

Hird F. J. R., Symons R. H., Weideman M. J., 1966, Biochem. J. 98:389.

Ikuma H., Thimann K. V., 1960, Plant Physiol. 35:557.

Ikuma H., Thimann K. V., 1963, Plant Cell Physiol. 4:113.

Ikuma H., Thimann K. V., 1964, Plant Physicl. 39:756.

James W. O., James A. L., 1940, New Phytol. 39:145.

Kallen R. G., Lowenstein J. M., 1962, Fed. Proc. 21:289.

Kornacker M.S., Lowenstein J. M., 1965, Biochem. J. 94:209.

Köves E., Varga M., 1959, Phyton 12:93.

Krampitz L. O., Lynen F., 1964, Biochem. Z. 341:97.

Krebs H. A., 1966, Abstr. IIId Meet. FEBS. M54, 143, Warsaw.

Krupka R. M., Towers G. H. N., 1958a, Canad. J. Bot. 36:165. 
Kiupka R. M., Towers G. H. N., 1958b, Canad. J. Bot. 36:179.

Kuczmak M., Tolbert N. E., 1962, Plant Physiol. 37:729.

Kursanow A. L., 1954, Wopr. bot. 1:131.

Kursanow A. L., 1957a, Izw. AN SSSR, Ser. biol. 689.

Kursanow A. L., 1957b, Unesco Intern. Conf. Radioisotop. Sci. Res., Paris NS/RIC/128.

Laties G. G., 1957, Survey Biol. Progr. 3:213.

Laties G. G., 1961, Abstr. Comm. 5th Intern. Congr. Biochem., Moscow, 324.

Laties G. G., 1964, Plant Physiol. 39:654.

Lewis K. F., Weinhouse F., 1951, J. Amer. Chem. Soc. 73:2500.

Lowenstein J. M., 1961, J. Theoret. Biol. 1:98.

Lowry O. H., Passonneau J. V., 1964a, Arch. Exper. Pathol. Pharmacol. 248:185.

Lowry O. H., Passonneau J. V., 1964b, Proc. 6th Intern. Congr. Biochem., New York, 705.

Mc Lennan D. H., Beevers H., Harley J. L., 1963, Biochem. J. 89:316.

Mapson L. W., Moustafa E. M., 1956, Biochem. J. 62:248.

Martin D. B., Vagelos P. R., 1962, J. Biol. Chem. 237:1797.

Massey V., 1953, Biochem. J. 53:67.

Mayer A. M., Mapson L. W., 1962, J. Exper. Bot. 13, 201.

Mayer A. M., Poljak off-Mayber A., 1963, The Germination of Seeds, Pergamon Press, Oxford. Meiss A. N., 1952, Conn. Agric. Exper. Sta. Bull. 553.

Millerd A., 1960, in "Encyklopaedia of Plant Physiology" W. Ruhland Ed., XII/1:620.

Miyamoto T., 1957, Mich. State Univ. Agric. Exper. Sta. Quart. Bull. 39:518.

Montgomery C. M., Webb J. L., 1954, Science 120:843.

Mossberg Y., Mayer A. M., Mapson L. W., 1964, J. Exper. Bot. 15:29.

Munch-Petersen A., 1944, Acta Physiol. Scand. 8:97.

Oota Y., Fuiji R., Sunoble Y., 1956, Physiol. Plant. 9:38.

Oota Y., Yamamoto Y., Fuiji R., 1954, J. Biochem. (Tokyo) 40:187.

Öpik H., 1965, J. Exper. Bot. 16:667.

Pack D. A., 1921, Bot. Gaz. 71:32.

Palmer M. J., DeKock P. C., Bacon J. S. D., 1963, Biochem. J. 86:484.

Pantelejew A. N., Kluszewa L. N., 1966, Wiestnik L. U. 123.

Parmeggiani A., Bowman R. H., 1963, Biochem. Biophys. Res. Comm. 12:268.

Passonneau J. V., Lowry O. H., 1963, Biochem. Biophys. Res. Comm. 13:372.

Payes G., Laties G. G., 1963, Biochem. Biophys. Res. Comm. 10:460.

Phillips J. W., 1947, Amer. J. Bot. 24:62.

Pierce E. C., Appleman C. D., 1943, Plant Physiol. 18:224.

Plaut G. W. E., Plaut K. A., 1952, J. Biol. Chem. 199:141.

Poljakoff-Mayber A., Evenari M., 1958, Physiol. Plant. 11:84.

Pritchard G. G., 1961, J. Exper. Bot. 12:353.

Pyriki C., Kunstmann F. W., 1956, Pharmazie 11:798.

Radecke H. R., 1965, Pharmazie 20:1.

Ramakrishnan C. V., 1954, Enzymologia 17:169.

Ramakrishnan C. V., Steel R., Lentz C. P.: 1955, Arch. Biochem. Biophys. 55:270.

Rasmussen G. K., Smith P. F., 1961, Plant Physiol. 36:99.

Richmond A. E., Dilley D. R., Dewey D. H., 1964, Plant Physiol. 39:1056.

Rollin P., 1964, Canad. J. Bot. 42:463.

Ruffo A., Te st a E., Adinolfi A., Pelizza G., 1962, Biochem. J. 85:588.

Sabala E., 1962, Farmacognosia 22:1.

Sanval B. D., Zink M. W., Stachow C. S., 1963, Biochem. Biophys. Res. Comm. 12:510.

Schneider A., 1941/42, Planta 32:227.

Schneider W., Streibich M. J., Hogeboom E. H., 1956, J. Biol. Chem. 222:969.

Schramm R. W., 1961, UAM Prace Wydz. BiNoZ Ser. Biol. 2.

Schramm R. W., Mossor T., Gierczak C., 1967, Acta Biochim. Pol. 14 (in press).

Simon E. W., Meany A. M., Sherwin T., 1963, Plant Physiol. 38, Suppl. XX. 
Sołdatienkow S. W., 1962, Trudy Petergof. Biol. Inst. 19:35.

Sołdatienkow S. W., Bykow O. D., 1964, Fizjoł. Rast. 11:515.

Sołdatienkow S. W., Iwanowa T. P., 1955, Ucz. Zap. LGU 186:19.

Sołdatienkow S. W., Mazurowa T. A., 1954, Biochimia 19:349.

Sołdatienkow S. W., Mazurowa T. A., 1956a, Biochimia 21:573.

Sołdatienkow S. W., Mazurowa T. A., 1956b, Biochimia 21:652.

Sołdatienkow S. W., Miriakubowa M. G., Mazurowa T. A., Kaługina J. W., 1965, Fizjoł. Rast. 12:457.

Sołdatienkow S. W., Wajnsztein E. A., 1966, Wiestnik L. U. 3:113.

Spencer A. F., Corman L., Lowenstein J. M., 1964, Biochem. J. 93:378.

Spencer A. F., Lowenstein J. M., 1962, J. Biol. Chem. 237:3640.

Srere P. A., 1959, J. Biol. Chem. 234:2544.

Srere P. A., 1965, Nature 205:766.

Srere P. A., Bhaduri A., 1962, Biochim. Biophys. Acta 59:487.

Srere P. A., Lipmann F., 1953, J. Amer. Chem. Soc. 75:4874.

Stanley R. G., Conn E. E., 1957, Plant Physiol. 32:412.

Stålfelt M. G., 1936, Biol. Ztbl. 46:1.

Stiles W., 1960, in "Encyclopaedia of Plant Physiology" W. Ruhland Ed., XII/2, 465.

Stiles W., Leach W., 1932, Proc. Roy. Soc. B. 111:338.

Stoklasa J., 1926, Ber. D. Bot. Ges. 44:248.

Stumpf P. K., 1952, Ann. Rev. Plant Physiol. 3:27.

Stumpf P. K., 1960, in "Encyclopaedia of Plant Physiology" W. Ruhland Ed., XII/1, 572.

Switzer C. M., Smith F. G., 1957, Canad. J. Bot. 35:515.

Takahashi N., Moroo T., Hashimoto Y., Yamaki T., 1962, Bot. Mag. (Tokyo) 75:163

Täufel K., Behnke U., 1956, Ernährungsforsch. 1:277.

Täufel K., Krusen F., 1952, Biochem. Z. 322:375.

Täufel K., Pohloudek-Fabini R., 1954, Pharmazie 9:511.

Täufel K., Pohloudek-Fabini R., 1955a, Biochem. Z. 326:280.

Täufel K., Pohloudek-Fabini R., 1955b, Biochem. Z. 326:317.

Tchen T. T., Vennesland B., 1955, J. Biol. Chem. 213:533.

Tchen T. T., Loevus F. A., Vennesland B., 1955, J. Biol. Chem. 213:547.

Tombesi L., Ruggieri G., Antoni A., 1955, Ann. Sperim. Agric. 9:48.

Trueloye B., 1962, Ann. Bot. 26:147.

Turner E. R., Quartley C. E., 1956, J. Exper. Bot. 7:362.

Turner J. S., 1960, in "Encyclopaedia of Plant Physiology" W. Ruhland Ed., XII/2:42.

Van Sumere C. F., 1960, in "Phenolics in Plants in Health and Disease" J. B. Pridham Ed., Per-• gamon Press, Oxford.

Varga M., 1957, Acta Biol. Szeged. 3:225.

Vickery H. B., 1956, Plant Physiol. 31:455.

Vickery H. B., 1959, Plant Physiol. 34:418.

Vickery H. B., Zelitch I., 1960, J. Biol. Chem. 235:1871.

Viňuela E., Salas M. L., Salas M., Sols A., 1964, Biochem. Biophys. Res. Comm. 15:143. Wager H. G., 1961, J. Exper. Bot. 12:34.

Webb J. A., Fowden L., 1955, Biochem. J. 61:1.

Wilkinson B. G., 1958, J. Hort. Sci. 33:49.

Williamson J. R., Jones E. A., Azzone G. F., 1964, Biochem. Biophys. Res. Comm. 17:696. Wray J. L., Brown A. P., 1966, Biochem. J. 98:44P.

Zelitch I., 1964, Ann. Rev., Plant. Physiol. 15:121. 


\section{Rola kwasów organicznych w kielkowaniu nasion}

\section{Streszczenie}

W procesie kiełkowania nasion aktywną rolę odgrywają kwasy organiczne występujące powszechnie we wszystkich nasionach i znajdujące się w nich od momentu osiągnięcia zdolności kiełkowania: kwas cytrynowy, kwas jabłkowy i — być może — niezbadane bliżej kwasy, będące produktami pierwotnego utleniania cukrów prostych (kwasy cukrowe). Ilość tych kwasów, szczególnie kwasu cytrynowego, jest bardzo różna w nasionach różnych gatunków. Kwas cytrynowy i jabłkowy odgrywają prawdopodobnie bezpośrednią rolę w metabolizmie zarodka i osi siewki, natomiast nie uczestniczą aktywnie w metabolizmie liścieni, gdzie występują w stosunkowo dużych ilościach. Przyjmuje się natomiast, że w liścieniach kwasy te, szczególnie cytrynowy, działają jako regulatory procesów oksydoredukcyjnych, stymulując fazę tlenową oddychania i fosforylację oksydacyjną. Prawdopodobnie na tej działalności polega obserwowana przez wielu badaczy niezbędność kwasu cytrynowego do procesu kiełkowania nasion. $Z$ chwilą uruchomienia przez siewkę procesu fotosyntezy przejmuje on rolę pełnioną pierwotnie w kiełkujących nasionach przez kwas cytrynowy.

\section{Katedra Biochemii}

Uniwersytetu im. A. Mickiewicza, Poznań 